\title{
Neurological disease in HIV-infected patients in the era of highly active antiretroviral treatment: a Brazilian experience
}

\author{
Doença neurológica em pacientes infectados pelo HIV na era da terapia \\ anti-retroviral altamente ativa: uma experiência brasileira
}

\author{
Jacqueline Ferreira de Oliveira ${ }^{1}$, Dirceu Bartolomeu Greco ${ }^{2}$, Guilherme Correa Oliveira ${ }^{3}$, \\ Paulo Pereira Christo ${ }^{1}$, Mark Drew Crosland Guimarães ${ }^{4}$ \\ and Rodrigo Corrêa-Oliveira ${ }^{3}$
}

\begin{abstract}
To study characteristics of neurological disorders in HIV/AIDS patients and their relationship to highly active antiretroviral treatment, a cross-sectional study was conducted in an infectious disease public hospital in Belo Horizonte, Brazil, between February 1999 and March 2000. Of the 417 patients enrolled, neurological disease was observed in 194 (46.5\%) and a new AIDS-defining neurological event developed in $23.7 \%$ of individuals. Toxoplasmosis (42.3\%), cryptococcosis meningitis (12.9\%) and tuberculosis (10.8\%) were the most common causes of neurological complications. The majority (79.3\%) of patients were on highly active antiretroviral treatment and these individuals using HAART showed higher CD4 cell counts $(p=0.014)$ and presented stable neurological disease $(p=0.0001)$, although no difference was found with respect to the profile of neurological complications. The neurological diseases continue to be a frequent complication of HIV/AIDS and infections are still its main causes in Brazil, even in the highly active antiretroviral treatment era.
\end{abstract}

Key-words: HIV infection. AIDS. Neurological disease. Highly active antiretroviral treatment. Brazil.

\begin{abstract}
RESUMO
Com o objetivo de estudar as doenças neurológicas em pacientes HIV/AIDS e sua relação com a terapia anti-retroviral altamente ativa, foi realizado estudo transversal em hospital público de doenças infecciosas de Belo Horizonte, Brasil, no período de fevereiro de 1999 a março de 2000. Doença neurológica foi observada em 194 (46,5\%) dos 417 indivíduos incluídos e um novo episódio de doença neurológica definidora de AIDS ocorreu em 23,7\% pacientes. Toxoplasmose (42,3\%), criptococose (12,9\%) e tuberculose (10,8\%) foram as principais causas de complicações neurológicas. A maioria dos pacientes estava em uso de terapia anti-retroviral altamente ativa (79,3\%) e esses indivíduos apresentaram maiores contagens de linfócitos CD4 ( $p=0,014)$ e maior freqüência de doença neurológica clinicamente estável, embora não tenha havido diferença no perfil etiológico das complicações neurológicas. As doenças neurológicas continuam sendo causas freqüentes de complicações da infecção pelo HIV/AIDS no Brasil, e a despeito da terapia anti-retroviral altamente ativa, as infecções são ainda a principal etiologia das doenças do sistema nervoso.
\end{abstract}

Palavras-chaves: Infecção pelo HIV. SIDA. Doença neurológica. Terapia anti-retroviral altamente ativa. Brasil.

\footnotetext{
1.Hospital Eduardo de Menezes, Minas Gerais Hospital State Foundation, Belo Horizonte, MG. 2. Infectious Disease Service, Federal University of Minas Gerais School of Medicine, Belo Horizonte, MG. 3. René Rachou Research Center, Oswaldo Cruz Foundation,Belo Horizonte, MG. 4. Department of Preventive and Social Medicine, Federal University of Minas Gerais School of Medicine, Belo Horizonte, MG, Brazil.

Address to: Dra. Jacqueline Ferreira de Oliveira. Hospital Eduardo de Menezes. R. Dr. Cristiano Rezende 2213, Bonsucesso, $30622-020$ Belo Horizonte, MG, Brasil. Tel: $55313383-8000$, Fax: $55313383-8526$

e-mail: jgfo@terra.com.br

Recebido para publicação em 18/4/2005

Aceito em 25/1/2006
} 
Neurological diseases occur frequently in individuals infected with human immunodeficiency virus type - 1 (HIV-1) and significantly affect their functional capacity, quality of life and survival ${ }^{14} 18$.

Early in the AIDS epidemic, neurological manifestations were reported in $31 \%$ to $70 \%$ of all HIV1-infected patients ${ }^{1933}$. Since the highly active antiretroviral therapy (HAART) has emerged however, multiple studies confirm a decrease in the incidence, as well as a change in the presentation of central nervous system (CNS) opportunistic infections and HIV associated dementia (HAD) in industrialized countries 711516202126303637.

The impact of HAART on the HIV-associated neurological disorders in developing countries still remains unclear. Limited access to antiretroviral therapy in addition to specific social-epidemiological conditions may produce a different picture compared with the United States and Europe 242739 .

In Brazil, a public health program was implemented in 1996 and provides free treatment to approximately 141,000 Brazilians with HIV infection ${ }^{13}{ }^{34}$. The effectiveness of the program has already been demonstrated in the reduction of AIDS related death ${ }^{27}{ }^{34}$ and in a significant decline of certain opportunistic infections ${ }^{12}$. Particularly in the field of neurological disease, however, there is limited information available. Most of the reports concerning the epidemiology of HIV/AIDS neurological disorders in Brazil were published prior to combined antiretroviral therapy ${ }^{3625282938}$.

In this study, we determined the frequency of neurological disorders in an AIDS reference center in Brazil in the era of HAART, described the spectrum of its main etiologies and assessed the relationship between neurological diseases and antiretroviral therapy.

\section{MATERIAL AND METHODS}

This cross-sectional study was conducted in a public reference infectious disease hospital, Hospital Eduardo de Menezes (HEM), the main tertiary hospital for HIV/AIDS patients in the metropolitan area of Belo Horizonte (2.8 million inhabitants), Brazil, during the period of February, 1999 to March, 2000.

Patients. All adult HIV1-infected individuals admitted were evaluated for current neurological manifestations and/or previous AIDS-defining neurological diagnosis. Neurological manifestations were defined as the presence of any altered state of consciousness, cognitive abnormalities, motor and/or sensitivity disturbances, behavior disorders, ataxia and dizziness, cranial nervous deficit, seizures or headaches other than primary. AIDS-defining neurological diagnoses were defined according to the Centers for Disease Control, CDC/93 criteria ${ }^{4}$.

All medical records were reviewed for information regarding demographic variables, sexual behavior, CD4+ cell counts and HIV-1 viral load. Plasma HIV-1 RNA, expressed as copies/ml was measured by nucleic acid sequence based amplification (NASBA), with a level of detection of 80 -copies $/ \mathrm{ml}$. Previous access to
HIV related medical care prior to hospitalization and antiretroviral regime use in the 6 months prior to the evaluation period were examined. The antiretroviral treatment was classified in (1) no therapy; (2) dual therapy - patients using a combination of 2 nucleoside transcriptase reverse inhibitors; (3) HAARTpatients using three antiretroviral drugs defined as a combination of protease inhibitors (PI) or non nucleoside transcriptase reverse inhibitors (NNITR) plus two nucleoside transcriptase reverse inhibitors.

The individuals included in the study were classified into groups according to their neurological disease profile: (i) stable, i.e., patients with previous AIDS-related neurological disorders, but who were free of neurological symptoms; (ii) symptomatic, i.e., patients with signs or symptoms of neurological manifestations at admission or at any time during hospitalization. The symptomatic group was considered as new or recurrent cases of neurological disease, respectively, if the neurological diagnosis has been previous established.

The criteria for HIV-associated dementia were defined according to the AIDS Task Force of the American Academy of Neurology ${ }^{1}$. Primary cerebral lymphoma was diagnosed in patients with unifocal enhancing mass lesions shown by computerized tomography (CT) and positive findings in brain biopsy. Toxoplasmosis encephalitis was defined in patients with focal signs and symptoms, multifocal enhancing mass lesions in CT and improvement of the symptoms after initiation of antitoxoplasma treatment (therapy with pyrimethamine and sulfadiazine or clindamycin). Cryptococcal meningitis was considered in the presence of typical symptoms and detection of the cryptococcal antigen or direct identification of cryptococcal organisms and a positive culture in cerebrospinal fluid (CSF). Tuberculosis was presumed by typical symptoms of basal meningitis or focal sign and symptoms in addition to predominance of lymphocytes with high protein levels in CSF followed by the improvement of symptoms and CSF alterations after tuberculostatic treatment or a positive culture for Mycobacterium tuberculosis in CSF. Progressive multifocal leukoencephalopathy (PML) was defined in patients with progressive focal signs and symptoms, a decline in cognitive function and multifocal non-enhancing white matter lesions in the CT. Cytomegalovirus (CMV) encephalitis was defined as the presence of diffuse neurological signs and symptoms and CT nonspecific findings such as ventriculomegaly and periventricular enhancement associated with a positive protein chain reaction (PCR) for CMV DNA in CSF. Herpes simplex virus (HSV) and varicella zoster virus (VZV) encephalitis were considered in the presence of diffuse or focal signs and symptoms, non-enhancing focal lesions in the CT with typical pox lesions or herpes zoster. The detection of these viruses in CSF by PCR analysis was not available. Neurosyphilis diagnosis was based on the combination of reactive serological tests and abnormalities of CFS cell count or protein or a reactive VDRL-CSF with or without manifestations 5 . Bacterial meningitis was diagnosed by detection of bacteria in GRAM stain and positive latex for bacterial antigens or culture in CSF. Other diagnoses considered were psychiatric disturbances and toxic-metabolic encephalopathy. Despite extensive 
investigation some neurological disorders were considered unspecific when no cause could not be determined.

Data analysis. Statistical tests: chi-square test with Yates correction and the student $t$-test, were performed using EpiInfo 2000 version 1.12 software ceded by the Centers for Disease Control and Prevention. For all analyses $\mathrm{p}$ values $<0.05$ were considered statistically significant.

Ethics. The Ethical Committee on Human Experimentation of the University of Minas Gerais School of Medicine and the Eduardo de Menezes Hospital approved the study.

\section{RESULTS}

Between February 1999 and March 2000, a total of 417 HIV1-infected patients were admitted to the HEM, of which 194 (46.5\%) presented neurological disease; $80.9 \%$ with symptomatic and $19.1 \%$ with stable neurological disease, respectively. Among the symptomatic patients $(n=157)$, new AIDS-defining neurological events were observed in 99 (63.1\%) patients, recurrence was observed in 25 (15.9\%), and $33(21 \%)$ individuals developed non-AIDS defining or nonspecific lesions. The overall proportion of new AIDSdefining neurological diagnoses was 23.7\% (99/417).

The descriptive characteristics of those with neurological disorders can be seen in Table 1. Age ranged from 18 to 65 years old (mean age $=35.8 \pm 0.6), 135$ patients $(69.6 \%)$ were male, $142(89.3 \%)$ had a low education level ( $\leq 8$ years) and 98 (80.3\%) acquired HIV through sexual transmission. The mean T lymphocyte CD4 cell count was $93.9 \times 10^{6} / 1(\mathrm{SD}=110.6)$

Table 1 - Sociodemographic, laboratorial and therapeutic characteristics of HIV-infected patients (n=194) with neurological disease at Hospital Eduardo de Menezes, Belo Horizonte, Brazil, 1999-2000.

\begin{tabular}{|c|c|c|c|}
\hline Characteristics & № & $\% *$ & Mean (SEM) \\
\hline \multicolumn{4}{|l|}{ Gender } \\
\hline male & 135 & 69.6 & \\
\hline female & 59 & 30.4 & \\
\hline Mean age (years) & & & $35.8 \pm 0.6$ \\
\hline Sexual exposure to HIV & 98 & 80.3 & \\
\hline Education level (< 8 years) & 142 & 89.3 & \\
\hline CD $4+$ cell count $\left(\times 10^{6} /\right)$ & & & $93.9 \pm 110.6$ \\
\hline Viral load count (copies/mm $\mathrm{mm}^{3}$ ) & & & $28,854 \pm 602.3$ \\
\hline \multicolumn{4}{|l|}{ HIV diagnosis: } \\
\hline pre-admission & 156 & 80.4 & \\
\hline at hospital & 38 & 19.6 & \\
\hline \multicolumn{4}{|l|}{ Previous outpatient care $(n=148)$} \\
\hline yes & 115 & 77.7 & \\
\hline no & 33 & 22.3 & \\
\hline \multicolumn{4}{|l|}{ Antiretroviral therapy $(n=146)$} \\
\hline yes & 111 & 76.1 & \\
\hline no & 35 & 23.9 & \\
\hline \multicolumn{4}{|l|}{ Antiretroviral regime $(\mathrm{n}=111)$} \\
\hline HAART & 88 & 79.3 & \\
\hline dual & 12 & 10.8 & \\
\hline no information & 11 & 9.9 & \\
\hline
\end{tabular}

* Numbers vary due to missing values and mean plasma HIV-1 RNA was 28,854 copies $/ \mathrm{mm}^{3}$ $(\mathrm{SD}=602.3)$. Thirty-eight $(19.6 \%)$ individuals with neurological disease were diagnosed with HIV-1 infection at the hospital, while $156(80.4 \%)$ patients presented a previous well-defined diagnosis, among which 115 (77.7\%) were under HIV outpatient care prior to admission. Finally, 111 (76.1\%) had been on antiretroviral therapy in the 6 months prior to the evaluation period, among which, 88 (79.3\%) had been on HAART, $12(10.8 \%)$ on dual therapy and for $11(9.9 \%)$ individuals there was no information regarding the antiretroviral scheme used.

Infections occurred in $151(77.8 \%)$ patients. Toxoplasmosis was the most frequent opportunistic infectious disease (42.3\%), followed by cryptococcosis meningitis $(12.9 \%)$ and tuberculosis (10.8\%) (Table 2). HIV-associated dementia was observed in $9(4.6 \%)$ cases in this series and primary CNS lymphoma in only one $(0.5 \%)$ patient. Despite extensive neurodiagnostic and neuroimaging evaluation, no etiology was defined in 16 (8.3\%) of the individuals.

Table 2 - Causes of neurological disease in HIV-1 infected patients (n=194) at Hospital Eduardo de Menezes, Belo Horizonte, Brazil, 1999-2000.

\begin{tabular}{lcc}
\hline Etiology & o & \% \\
\hline Infection & 82 & \\
$\quad$ toxoplasmosis & 25 & 42.3 \\
$\quad$ cryptococcal meningitis & 21 & 12.9 \\
tuberculosis & 7 & 10.8 \\
PML & 3 & 3.6 \\
CMV encephalitis & 2 & 1.6 \\
bacterial & 2 & 1.0 \\
$\quad$ syphilis & 2 & 1.0 \\
VZV encephalitis & 1 & 1.0 \\
HSV encephalitis & 6 & 0.5 \\
$\quad 2$ infectious diseases & 16 & 3.1 \\
Non-defined etiology & 9 & 8.3 \\
HIV dementia & 7 & 4.6 \\
Toxic and metabolic encephalopathy & 5 & 3.6 \\
Psychiatric disorders & 5 & 2.6 \\
Other causes & 1 & 2.6 \\
Neoplasic disease & & 0.5 \\
\hline
\end{tabular}

PML - progressive multifocal leukoencephalopathy. CMV - cytomegalovirus. HSV - human simplex virus. VZV - human zoster virus

Symptomatic neurological HIV-infected patients presented statistically significant lower T CD4 cell counts $\left(\leq 100\right.$ cells $\left./ \mathrm{mm}^{3}\right)$ $(\mathrm{p}=0.045)$, were less likely to have used previous HIV outpatient care $(\mathrm{p}=0.005)$ or to have used antiretroviral treatment $(\mathrm{p}=0.001)$, compared to stable patients. There were no differences which respect to gender, age, educational level and viral load between the two groups (Table 3).

The variables that were associated with being on HAART were lymphocyte T CD $4+$ cell count $\left(\geq 200\right.$ cells $\left./ \mathrm{mm}^{3}\right) \quad(\mathrm{p}=0.014)$ and stable neurological profile $(\mathrm{p}=0.0001)$ (Table 4$)$. There were no differences between the antiretroviral schemes with respect to viral load, overall AIDS-defining neurological disease or overall opportunistic infection. However, the numbers were too small for proper statistical assessment. 
Table 3 - Clinical and laboratorial conditions associated with stable or symptomatic neurological disease in HIV-infected patients at Hospital Eduardo de Menezes, Belo Horizonte, Brazil, 1999-2000.

\begin{tabular}{|c|c|c|c|c|c|}
\hline \multirow[b]{2}{*}{ Variable } & \multicolumn{2}{|c|}{$\begin{array}{c}\text { Symptomatic } \\
\text { neurological disease }\end{array}$} & \multicolumn{2}{|c|}{$\begin{array}{c}\text { Stable } \\
\text { neurological disease }\end{array}$} & \multirow[b]{2}{*}{ P-value } \\
\hline & $(n=157)$ & $\% *$ & $(\mathrm{n}=37)$ & \%* & \\
\hline \multicolumn{6}{|l|}{ Gender } \\
\hline male & 108 & 68.8 & 27 & 73.0 & 0.77 \\
\hline female & 49 & 31.2 & 10 & 27.0 & \\
\hline \multicolumn{6}{|l|}{ Age } \\
\hline$<35$ & 74 & 47.1 & 17 & 45.9 & 0.96 \\
\hline$\geq 35$ & 83 & 52.9 & 20 & 54.1 & \\
\hline \multicolumn{6}{|l|}{ Education level $(\mathrm{n}=159)$} \\
\hline$\leq 8$ years & 111 & 87.4 & 31 & 96.9 & 0,10 \\
\hline$>8$ years & 16 & 12.6 & 1 & 3.1 & \\
\hline \multicolumn{6}{|l|}{ CD4 cell count $(\mathrm{n}=139)$} \\
\hline$<100 \times 10^{6} /$ & 80 & 72.1 & 14 & 50.0 & 0.045 \\
\hline$\geq 100 \times 10^{6} \Lambda$ & 31 & 27.9 & 14 & 50.0 & \\
\hline \multicolumn{6}{|l|}{ HIV viral load $(\mathrm{n}=107)$} \\
\hline$<80$ copies $/ \mathrm{mm}^{3}$ & 8 & 9.6 & 1 & 4.2 & 0.48 \\
\hline $80-55,000$ copie $/ \mathrm{mm}^{3}$ & 38 & 45.8 & 14 & 58.3 & \\
\hline$\geq 55,000$ copies $/ \mathrm{mm}^{3}$ & 37 & 44.6 & 9 & 37.5 & \\
\hline \multicolumn{6}{|c|}{ Previous outpatient care $(\mathrm{n}=148)$} \\
\hline yes & 82 & 88.4 & 33 & 97.1 & 0.005 \\
\hline no & 31 & 27.4 & 1 & 2.9 & \\
\hline \multicolumn{6}{|l|}{ Antiretroviral therapy $(\mathrm{n}=146)$} \\
\hline yes & 76 & 69.1 & 35 & 97.2 & 0.001 \\
\hline none & 34 & 30.9 & 1 & 2.9 & \\
\hline
\end{tabular}

Table 4-Analyses of HIV1-infected patients (n=194) with neurological disease according to some clinical and laboratorial conditions and the antiretroviral scheme at Hospital Eduardo de Menezes, Belo Horizonte, Brazil, 1999-2000.

\begin{tabular}{|c|c|c|c|}
\hline Variable & $\begin{array}{c}\text { HAART } \\
\mathrm{n}^{0} *\end{array}$ & $\begin{array}{c}\text { No therapy } \\
\mathrm{n}^{0 *}\end{array}$ & $\mathrm{p}$-value \\
\hline \multicolumn{4}{|l|}{ CD4 cell count $(n=94)$} \\
\hline$<200 \times 10^{6} \Lambda$ & 55 & 26 & 0.014 \\
\hline$\geq 200 \times 10^{6} \Lambda$ & 12 & 1 & \\
\hline \multicolumn{4}{|l|}{ HIV viral load $(\mathrm{n}=80)$} \\
\hline$<55,000$ copie $/ \mathrm{mm}^{3}$ & 33 & 15 & 0.96 \\
\hline$\geq 55,000$ copie $/ \mathrm{mm}^{3}$ & 21 & 11 & \\
\hline \multicolumn{4}{|l|}{ Neurological disease profile } \\
\hline symptomatic & 54 & 34 & 0.0001 \\
\hline stable & 34 & 1 & \\
\hline \multicolumn{4}{|c|}{ AIDS-defining neurological disease ${ }^{* * *}$} \\
\hline yes & 66 & 26 & 0.88 \\
\hline no & 22 & 9 & \\
\hline
\end{tabular}

Cause of AIDS-defining

neurological disease $(\mathrm{n}=92)$

$\begin{array}{llll}\text { opportunistic infection } & 65 & 24 & 0.19\end{array}$

non-infectious

2

* Numbers vary due to missing values. ** CDC Centers for Disease Control and Prevention: revised classification system for HIV infection and expanded surveillance of definition for AIDS among adolescents and adults 4 .

\section{DISCUSSION}

This is the first study on neurological disorders in the HAART era in Brazil. The most important finding of the study was that neurological disorders continue to be a frequent complication in HIV1-infected patients. The observed proportion (46.5\%) of cases was very similar to publications prior to 1996. In two clinical series between 1989 and 1991, Vecino et $\mathrm{al}^{38}$ found a prevalence of $60.4 \%$ for neurological disease and Puccioni-Sohler et $\mathrm{a}^{28}$ demonstrated a frequency of $26 \%$ of neurological complications in two distinct Brazilian university hospitals. Our results were also in agreement to that found a prevalence of $42.7 \%$ for neurological manifestations in São Paulo?.

Brazil is the first developing country to have implemented a large-scale universal antiretroviral distribution program and approximately 141,000 patients now receive antiretroviral treatment through the public health system. This study describes the overall characteristics of neurological disorders in HIV after universal access to HAART in Brazil. In this context, the current findings may indicate an apparent contradiction. Considering that $76 \%$ of neurological patients were on antiretroviral treatment and nearly $80 \%$ of them on HAART, a lower prevalence of neurological disorders would be expected. Although a complete explanation is difficult, the results presented here could be partially biased by the severity of the patients' disease conditions. Data were collected from a hospitalized population, presumably more immunosuppressed than outpatients. As demonstrated by the low mean T CD $4+$ cell count $\left(93.9 \times 10^{6}\right.$ cell/ $\left./\right)$, these patients indeed presented end-stage AIDS and were expected to develop more opportunistic complications, including CNS diseases. The possibility of partial or deferred immune reconstitution in response to HAART should also be considered. The drug regimen and the onset the antiretroviral therapy were also not investigated. It is possible that patients who had recently started HAART may have been subject to a higher risk of a neurological event. Other factors such as a poor adherence to HAART, a less potent regimen, a failing regimen, or a recent rescue scheme may have contributed to the increased risk of neurological complications.

We characterized the profile of patients who were developing neurological disease in the era of combined antiretroviral treatment. Individuals with advanced immunodeficiency, T CD4+ cell counts $<100 / \mathrm{mm}^{3}(\mathrm{p}=0.045)$, those without previous HIV outpatient care $(\mathrm{p}=0.005)$ and patients not receiving antiretroviral therapy $(\mathrm{p}=0,001)$ showed a statistically significant probability for the manifestation of neurological symptomatic disorders. The percentage of patients on HAART was also significantly higher in the group of neurological stable patients $(\mathrm{p}=0.0001)$, compared to the symptomatic patients. This same profile has been observed in the developed world, where central nervous system diseases still occur, particularly in individuals who do not take antiretroviral drugs, but even in those who do take theses agents ${ }^{815202231}$.

Infections were the most common cause of neurological disease and occurred in $151(77.8 \%)$ patients, which suggests that the spectrum of neurological disease etiologies has not changed in Brazil. Our results are consistent with Chimelli at al ${ }^{6}$ in a pre-HAART report on 252 autopsy cases who observed a $65.4 \%$ incidence of opportunistic infections and Fragoso et al ${ }^{9}$ who found an $80 \%$ rate of opportunistic neurological disease in 
an early-HAART Brazilian series. It is probable that geographic and socioeconomic factors interfere with the evolution of the HIV-1 infection, possibly by enhancing the risk of exposure to infectious agents. Reports from India ${ }^{1732}$ and Mexico ${ }^{10} 23$ confirm the predominance of infectious neurological disorders over HIV dementia and neoplasic disease.

Toxoplasmosis was still the most common opportunistic infection in the central nervous system (42.3\%) and cryptococcal meningitis was the second (12.9\%). The present study could not confirm the low frequencies of toxoplasmosis (2.2\% to $8 \%)$ and of cryptococcosis $(0.8 \%$ to $4.9 \%)$ documented by Masliah et $\mathrm{al}^{21}$ Sacktor et $\mathrm{a}^{31}$, Mascke et $\mathrm{al}^{20}$, Jellinger et $\mathrm{al}^{15}$, Neuenburg et $\mathrm{al}^{26}$, and Gray et $\mathrm{al}^{11}$ in the HAART era in the developed world. Tuberculosis was the third cause (10.8\%) of opportunistic neurological infection in this study in agreement with statistics from tropical areas and in developing countries ${ }^{17}{ }^{32}$. The frequency of HIV associated dementia and primary CNS lymphoma were very low in this Brazilian series, probably misdiagnosed because the concomitance of opportunistic infections and the limited access to cerebral biopsy and modern imaging.

We believe there are several limitations to the current study. Only HIV-infected inpatients were considered. It is unknown whether similar results would be obtained in other groups, such as outpatient care or with a higher T CD 4+ cell count and higher adherence. Data related to antiretroviral regimens and compliance was not always available. The low specificity of neurological signs and symptoms and the limited access to diagnostic methods could have contributed to the high prevalence of presumptive opportunistic infections and may have impaired the recognition of non-opportunistic AIDS-defining neurological disorders.

A larger, multicenter study to analyze the temporal trends of the neurological disease in HIV/AIDS patients in Brazil and its changing profile is warranted. In addition, earlier HIV testing, diagnosis and proper follow-up, including primary prophylaxis for opportunistic infections and HAART, should be emphasized as public health policies for the treatment and prevention of AIDS in Brazil and other developing countries.

\section{REFERENCES}

1. American Academy of Neurology. Nomenclature and research case definitions for neurological manifestations of human immunodeficiency virus type 1 (HIV-1) infection. Report of a Working Group of the American Academy of Neurology AIDS Task Force. Neurology 41:778-785, 1991.

2. Cahn P, Belloso WH, Murillo J, Prada -Trujillo G. AIDS in Latin America. Infectious Disease Clinics of North America 14: 185-209, 2000.

3. Câmara VD, Tavares W, Ribeiro da Rocha MP, Chimelli LC, Dumas-Hahn M. Contribuição ao conhecimento das alterações neurológicas em pacientes com SIDA. Arquivos Neuropsiquiatria 53: 53-59, 1995.

4. Centers for Disease Control and Prevention. Revised classification system for HIV infection and expanded surveillance of definition for AIDS among adolescents and adults. Morbidity and Mortality Weekly Report 41:1-19, 1992.

5. Centers for Disease Control and Prevention. Sexually Transmitted Disease Treatment Guideline. Morbidity and Mortality Weekly Report RR 6:18-30, 2002 .

6. Chimelli L, Rosemberg S, Hahn MD, Lopes MBS, Barretto Netto M. Pathology of central nervous system in patients infected with human immunodeficiency virus (HIV): a report of 252 autopsy cases from Brazil. Neuropathology and Applied Neurobiology 18: 478-488, 1992.

7. D’Arminio-Monforte A, Cinque P, Mocrof A, Goebel FD, Antunes F, Katlama C, Justesen US, Vella S, Kirk 0, Lundgren J, EuroSIDA Study Group. Changing incidence of central nervous system disease in the EUROSIDA cohort. Annals of Neurology 55: 320-328, 2004.

8. D‘ Arminio-Monforte A, Duca PG, Vago L, Grassi MP, Moroni M. Decreasing incidence of CNS AIDS-defining events associated with antiretroviral therapy. Neurology 54: 1856-1859, 2000.

9. Fragoso YD, Mendes V, Adamo APM, Bosco LP, Tavares CAF. Neurological manifestations of AIDS: a review of fifty cases in Santos. Revista Paulista de Medicina 116: 1715-1720, 1998.

10. Gongora-Rivera F, Santos-Zambrano J, Moreno-Andrade T, Calzada-Lopez P, Soto-Hernandez JL. The clinical spectrum of neurological manifestations in AIDS patients in Mexico. Archives of Medical Research 31: 393-398, 2000.

11. Gray F, Chretien F, Vallat-Decouvelaere AV, Scaravilli F. The changing pattern of HIV neuropathology in the HAART era. Journal of Neuropathology Experimental Neurology 62: 429-940, 2003.

12. Guimarães MDC. Temporal trends in AIDS-associated opportunistic infections in Brazil 1980-1999. Cadernos de Saúde Pública 16 (supl 1): 21-36, 2000.

13. Hofer CB, Schechter M, Harrison LH. Effectiveness of antiretroviral therapy among patients who attend public HIV clinics in Rio de Janeiro, Brazil. Journal of Acquired Immunodeficiency Syndrome 36: 967-971, 2004.

14. Holloway RGJ, Kieburtz KD. Neurologic manifestations of human immunodeficiency virus infection. In: Mandell GL, Bennett JE, Dolin R (eds) Mandell, Douglas, and Bennett's principles and practice of infectious disease, $5^{\text {th }}$ edition, Churchill Livingstone, Philadelphia, p. 1432-1439, 2000.

15. Jellinger KA, Setinek U, Drlicek M, Böhm G, Steurer A, Lintner F. Neuropathology and general autopsy findings in AIDS during last 15 years. Acta of Neuropathology 100: 213-220, 2000.

16. Langford TD, Letendre SL, Larrea GJ, Masliah E. Changing patterns in the neuropathogenesis of HIV during the HAART era. Brain Pathology 13: 195-210, 2003.

17. Lanjewar DN, Jain PP, Shetty CR. Profile of central nervous system pathology in patients with AIDS: an autopsy study from India. AIDS 12: 309-313, 1998.

18. Lanska DJ. Epidemiology of human immunodeficiency virus infection and associated neurologic illness. Seminars in Neurology 19: 105-111, 1999.

19. Levy RM, Bredensen DE, Rosemblum M. Neurological manifestations of acquired immunodeficiency syndrome (AIDS): Experience at UCSF and review of the literature. Journal of Neurosurgery 62:475-495, 1985.

20. Maschke M, Kastrup O, Esser S, Ross B, Hengge U, Hufnagel A. Incidence and prevalence of neurological disorders associated with HIV since the introduction of highly active antiretroviral therapy (HAART). Journal of Neurology, Neurosurgery and Psychiatry 69: 376-380, 2000.

21. Masliah E, De Teresa MR, Mallory ME, Hansen LA. Changes in pathological findings at autopsy in AIDS cases for last 15 years. AIDS 14: 69-74, 2000.

22. Michelet C, Arvieux C, Fancois C, Besnier JM, Rogez JP, Breux JP, Souala F, Allavena C, Raffi F, Garre M, Cartier F. Opportunistic infections occurring during highly active antiretroviral treatment AIDS 12: 1815-1822, 1998.

23. Mohar A, Romo J, Salido F, Jessurun J, Ponce de Leon S, Reyes E, Volkon P, Larraza 0, Peredo MA, Cano C. The spectrum of clinical and pathological manifestations of AIDS in a consecutive series of autopsied patients in Mexico. AIDS 6: 467-473, 1992.

24. Moreira Junior ED, Silva N, Brites C, Carvalho EM, Bina JC, Badaró R, Jonhson $\mathrm{Jr}$ WD. Characteristics of the acquired immunodeficiency syndrome in Brazil. American Journal of Tropical Medicine and Hygiene 48: 687-692, 1993.

25. Netto JG, Collarile DC, Borges AFA, Biancalana MLN, Stefano HNV. Achados necroscópicos em pacientes com síndrome da imunodeficiência adquirida. Revista Paulista de Medicina 108:205-212, 1990.

26. Neuenburg JK, Brodt HR, Herndier BG, Bickel M, Bacchetti P, Price RW, Grant RM, Schlote W. HIV-related neuropathology, 1985 to 1999: rising 
prevalence of encephalopathy in the era of highly active antiretroviral therapy. Journal of Acquired Immune Deficiency Syndromes 31: 171-177, 2002.

27. Nobre V, Braga E, Rayes A, Serufo JC, Godoy P, Antunes F, Lambertucci JR. Opportunistic infections in patients with AIDS admitted to a university hospital of the Southeast of Brazil. Revista do Instituto de Medicina Tropical de São Paulo 45: 69-74, 2003.

28. Puccioni-Sohler M, Corrêa RB, Perez MA, Schechter M, Filho CR, Novis SAP. Complicações neurológicas da síndrome da imunodeficiência adquirida: Experiência do HUCFF - UFRJ. Arquivos de Neuropsiquiatria 49: 159-163, 1991.

29. Rosemberg S, Lopes MBS, Tsanaclis AM. Neuropathology of acquired immunodeficiency syndrome. Analysis of 22 Brazilian cases. Journal of Neurological Sciences 76: 187-198, 1986

30. Sacktor N. The epidemiology of human immunodeficiency virus-associated neurological disease in the era of highly active antiretroviral therapy. Journal of Neurovirology 8 (suppl 2): 115-122, 2002.

31. Sacktor N, Lyles RH, Skolasky R, Kleeberger MAS, Selnes OA, Milller EN, Becker JT, Cohen B, McArthur JC, The Multicenter AIDS Cohort Study. HIVassociated neurologic disease incidence changes: Multicenter AIDS Cohort Study, 1990-1998. Neurology 56: 257-260, 2001

32. Satishchandra P, Nalini A, Gourie-Devi M, Khanna N, Santosh V, Ravi V, Deasi A, Chandramuki A, Jayakumar PN, Shankar SK. Profile of neurologic disorders associated with HIV/AIDS from Bangalore, South India (198996). Indian Journal of Medical Research 111:14-23, 2000.
33. Snider WD, Simpson DM, Nielsen S, Gold JWM, Metroka CE, Posner JB. Neurological complications of acquired immune deficiency syndrome. Annals of Neurology 14:403-418, 1983.

34. Teixeira PR, Vitória MA, Barcarolo J. Antiretroviral treatment in resourcepoor settings: the Brazilian experience. AIDS 18 (suppl 3): S5-S7, 2004.

35. Trujillo JR, Garcia-Ramos G, Novak IS, Rivera VM, Huerta E, Essex M Neurologic manifestations of AIDS: a comparative study of two populations from Mexico and the United States. Journal of Acquired Immune Deficiency Syndromes and Human Retrovirology 8: 23-29, 1995.

36. Vago L, Bonetto S, Nebuloni M, Piergiorgio D, Carsanna L, Zerbi $\mathrm{P}$ D’Arminio-Monforte A. Pathological findings in the central nervous system of AIDS patients on assumed antiretroviral therapeutic regimens retrospective study of 1597 autopsies. AIDS 16: 1925-1928, 2002.

37. Vallat-Decouvelaere AV, Chretien F, Lorin de La Grandmaison G, Force G, Gray F. The neuropathology of HIV infection in the era of highly active antiretroviral treatment. Annals of Pathology 23:408-23, 2003.

38. Vecino MC, Rieder CRM, Melo LL. Manifestações neurológicas da síndrome da imunodeficiência adquirida: análise de 55 casos do Hospital de Clínicas de Porto Alegre. Revista da Associação Médica do Rio Grande do Sul 33: 109-116, 1993.

39. Vidal JE, Colombo FA, de Oliveira AC, Focaccia R, Pereira-Chioc C. PCR assay using cerebrospinal fluid for diagnosis of cerebral toxoplasmosis in Brazilin AIDS patients. Journal of Clinical Microbiology 42:4765-4768, 2004.

40. Wainstein MV, Ferreira L, Wolfenbuttel L, Golbspan L, Sprinz E, Kronfeld M, Edelweiss MI. Achados neuropatológicos na síndrome da imunodeficiência adquirida (SIDA): revisão de 138 casos. Revista da Sociedade Brasileira de Medicina Tropical 25: 95-99, 1992. 